\title{
On the Tragic of Mrs. Bovary From the Perspective of Utilitarianism
}

\author{
ZHANG Tian-yi, JIA Xiao-yun \\ University of Shanghai for Science and Technology, Shanghai, China
}

\begin{abstract}
Madame Bovary is a very famous work around the world. Many researches have been made on this great work from various aspects, such as female consciousness, love view, romanticism, and so on. The main character of this novel, Mrs. Bovary, blindly pursues her own business and finally leads to a tragic life. This kind of action is in line with the key point of utility. This article uses the principle of utilitarianism to analyze how it gradually puts Mrs. Bovary into abyss, aiming to express the perniciousness of utility towards people's life and warn humans to stay away from utilitarian circles in this modern economic society.
\end{abstract}

Keywords: Madame Bovary, utilitarianism, tragedy

\section{Introduction}

Madame Bovary is written by Gustave Flaubert. As a literary craftsman of 19th century, Flaubert gives a far-reaching impact on French literature, even on the world literature. When mentioning Gustave Flaubert, Li Jian Wu says: "creation is his life, words and sentences are the expressions of his emotion and art is his whole life” (Cheng, 2018). This novel tells a tragic story about a rural girl. After marrying a common doctor, she feels disappointed with this boring and common life because of her freakish pursuit of romanticism from her past experiences. So she starts two extramarital affairs in order to change her unsatisfied life. However, it's not the right way to get to her ideal life. Finally, suffering discard, usury, and other tragic things, she chooses to swallow arsenic to end her unhappy life.

\begin{abstract}
About Utilitarianism
About utilitarianism, there are different versions of its definition. Jeremy Bentham quotes Hume's explanation towards utilitarianism in his book A Fragment on Government, and he says: "in any actions, if the tendency is toward happiness, we call it its utility, and the tendency to deviate it is called a curse” (Bentham, 1995, p. 115). That's to say, the core of utilitarianism is "happiness”. In fact, western utilitarianism has a long history. It generates form ancient Greece and Rome, via medieval heritage and in the 16th century, utilitarian Bentham formally develops it into an officially theoretical wide and far-reaching influence theory in philosophy, law, ethics, politics, and economics (Zhang, 2016). The main western philosophers include James Mill, Jeremy Bentham, Richard Cumberland, Democritus, and Hume. Domestic utilitarian include Zhen-Zhao Nie and

ZHANG Tian-yi, Master of Arts, College of Foreign Languages, University of Shanghai for Science and Technology, Shanghai, China.

JIA Xiao-yun, associate professor, College of Foreign Languages, University of Shanghai for Science and Technology, Shanghai, China.
\end{abstract}


Mo-tse. Democritus thinks that the true meaning of happiness lies in the peace of the soul, to understand the pleasure in temperance, not the desire of mouth. The meaning of life is exploring the true happiness (Department of History of Foreign Philosophy, Peking University, 1961, p. 113).

In the book A Treatise of Human Nature, Hume uses "utilitarianism” to refer to the benefits that make people happy, especially the overall happiness rights and interests of human beings (Zhao, 2016).

James Mill is the famous British utilitarian thinker. He makes some modifications and supplements on the basis of Bentham's utilitarian happiness theory to form his own utilitarian happiness theory, which is the core of his utility theory (Tang, 2016). Mill thinks that utilitarianism insists on the Great Happiness Principle, and holds that actions are right in proportion as they tend to promote happiness, wrong as they tend to produce the reverse of happiness (Mill, 2007, p. 16). Mrs. Bovary’s pursuit of this unrealistic pleasure excessively all the time can be called utility. This kind of inappropriate attitude makes her life a complete mass and even kills her. So utilitarianism can be used to analyze the choices of Mrs. Bovary.

\section{Analysis of the Tragic of Mrs. Bovary From the Perspective of Utilitarianism}

Utilitarianism thinks the theory of morality is grounded on the theory of life-namely, pleasure, and freedom from pain, which are the only things describe as ends (Mill, 2007, p. 18). Mrs. Bovary follows this principle to choose a husband for herself. When her father asks her whether she is willing to get married with Bovary as his second wife, she agrees. The reason is that she wants to leave village and live in the city. Certainly, she thinks Bovary can make her happier, for she wants to change her current life.

But the uneasiness of her new position, or perhaps the disturbance caused by the presence of this man, had sufficed to make her believe that she at last felt that wondrous passion which, till then, like a great bird with rose-colored wings. (Flaubert, 2011, p. 35)

From the description in the text, it can be found that Mrs. Bovary wants "the wondrous passion", which lets her to make the decision of getting married with Charles Bovary. This utilitarian marriage is the beginning of the tragedy of Mrs. Bovary.

Utilitarianism thinks that happiness is the sole end of human action, and the promotion of it the test by which to judge of all human conduct; from whence it necessarily follows that it must be the criterion of morality, since a part is included in the whole (Mill, 2007, pp. 88-90). The marriage of Bovary and Mrs. Bovary is full of utilitarianism. Mrs. Bovary thinks Charles Bovary is the person who can take her away from the poor village and give her a chance of living in the city. She thinks being Charles Bovary' wife can make her get romantic love. So when her father asks her attitude towards this marriage, she answers "yes”. Because of being swayed by utilitarianism, she agrees on the tragic marriage arranged by her father, which leads to the following events and becomes the main course of the tragic ending.

At the beginning of the marriage, Charles Bovary and Mrs. Bovary feel very happy. With time going by, two people have different feelings. Charles Bovary does not know Mrs. Bovary before marriage. "Sometimes she would draw; and it was great amusement to Charles Bovary to stand there bolt upright and watch her bend over her cardboard". "Emma, on the other hand, knew how to look after her house”, "Charles Bovary finished by rising in his own esteem for possessing such a wife” (Flaubert, 2011, pp. 36-37). In his eye, Mrs. Bovary is totally different from the first wife of Charles Bovary; she is so beautiful and so brilliant that makes Charles Bovary's life better. However, it's a different situation for Emma. Peaceful but common life makes her feel 
boring. She cannot bear her common husband and dull life, which is far away from what she thought before marriage. Till then, she realizes that she is paying the price for her utilitarian decision of getting married with Charles Bovary. In order to seek colorful and interesting life to make herself happy, Mrs. Bovary has two extramarital affairs. Her first cicisbeo was Monsieur Rudolph. He is an estate near Yonville, where he has chateau and two farms. "He was of brutal temperament and intelligent perspicacity, having, moreover, had much to do with women, and knowing them well” (Flaubert, 2011, p. 117). Rodolphe thinks Mrs. Bovary is so beautiful and so special that he wants to possess her. Mrs. Bovary also wants to stay together with Rodolphe because it can give her happiness. Seeking for happiness is the biggest rule of utilitarianism (Mill, 2007, p. 28). So forced by utilitarianism, Mrs. Bovary again does something that is non-conformity with law, and she falls in love with Rodolphe to seek feeing of freshness and to change common life. She thinks her leman is so romantic that he could give her a kind of love, which always happens in the novel Mrs. Bovary has read before. So she seizes every chance to see him and to stay with him. To make it worse, one day when Mrs. Bovary decides to follow him to the ends of the Earth, Rodolphe only regards her as a "plaything", which breaks her beautiful adultery life and gives her a fatal blow. After that, Mrs. Bovary becomes so depressible and seems to take interest in nothing.

Although Emma's husband does not know why his wife gets ill suddenly, he takes her out to disperse her bad mood. Life is so amazing and unexpected. At this point, they meet another person, Leon, who was a trainee in the clinic before. Mrs. Bovary and Leon admire each other before Leon goes to Paris. They meet each other again after so many years, which lights the new hope for Emma. Leon wants to chase Mrs. Bovary to make up for his cowardice in the past. "Then, seeing her again after three years of absence his passion reawakened, he must, he thought, at last make up his mind to possess her” (Flaubert, 2011, p. 211). Mrs. Bovary also has her own intention of building relationship with Leno. This experience is also sweet and even happier than the last one, for Mrs. Bovary has more experience than ever. However, although she becomes crazier and spares no expense to make herself happy, she began to spend a lot of money on him and on their clandestine love affairs, as long as she can get her happiness. So under the deceit of Lheureux, Mrs. Bovary owes a lot of money. Although she tries many ways to raise money, it turns out to be a failure. At last, she feels hopeless, and ends up her life.

\section{Conclusion}

Madame Bovary is a very popular novel, so there are many researches on it. However, they seldom analyze it from the perspective of utilitarianism. Mrs. Bovary is the typical character of excessively pursuing happiness, which is the exact reason for her tragedy. She pays much attention to her happiness. The decision of marrying to Charles Bovary is the beginning of the tragic, which decides the following events. This kind of utilitarianism is shown on many aspects, such as her vanity. She gets married to Charles Bovary only for the departure from the poor village so that she can live a life like rich people in the city. In order to pursue her own happiness and get self-satisfaction, she experienced two extramarital affairs, which leads to her tragic life. In the current society, many people would like to seek quick success and instant benefits in order to pursue maximum profit, which easily makes the mistake of utility. If they do not change their attitudes in time, they would probably have suffered the same the consequences. 


\section{References}

Bentham, J. (1995). A fragment on government. (S. P. Shen, Trans.). Beijing: The Commercial Press.

Cheng, G. W. (2018). I read Wives and Concubines in Groups—enjoy novels in the dialogue between Su Tong and Mrs. Bovary's translators. Masterpieces Review, (2), 19-21.

Department of History of Foreign Philosophy, Peking University. (1961). Ancient Greek and Rome philosophy. Beijing: The Commercial Press.

Flaubert, G. (2011). Madame Bovary. Nanjing: Yinlin Publishing House.

Mill, J. (2007). Utilitarianism. Beijing: Jiuzhou Publishing House.

Tang, X. (2016). On Mill’s happiness from the perspective of utilitarianism. Journal of Hubei Correspondence University, 29(11), 90-91.

Yuan, Y. C. (2014). The origin of Emma's tragedy in Madame Bovary. Cultural Aspect, p. 89.

Zhang, Y. F. (2016). Utilitarianism and its impact on Contemporary China. Shang Dong: Shang Dong University.

Zhao, Z. S. (2016). Exploration on Bentham’s utilitarianism. Intelligence, p. 265. 